\title{
Influence of Purchase Characteristics in "MORE" Supermarket Outlets at Kadapa-An Emerging Market
}

\author{
Poornima D. ${ }^{1,2}$ \& Ashok D. ${ }^{1}$ \\ ${ }^{1}$ VIT Business School, VIT University, Vellore, Tamil Nadu, India \\ ${ }^{2}$ Global College of Engineering \& Technology, Kadapa, Andhra Pradesh, India \\ Correspondence: Poornima D., VIT Business School, VIT University, Vellore 632014, Tamil Nadu, India. Tel: \\ 91-96-4204-2211; 91-93-4530-7314. E-mail: purnima.shankar9@gmail.com; dashok@vit.ac.in
}

\author{
Received: May 15, 2013 Accepted: September 16, 2013 Online Published: November 29, 2013 \\ doi:10.5539/ass.v9n17p62 \\ URL: http://dx.doi.org/10.5539/ass.v9n17p62
}

\begin{abstract}
We have entered the 21 st century at a time when the demography of our small town and rural population is changing significantly to drive organized retail growth. Thus, 85 per cent of the retail boom which was focused only in the metros has started to infiltrate towards smaller cities and towns. These smaller cities and towns where organized retail is still in its early stages are classified as emerging Indian markets (Ali et al., 2010). Literature indicates that store choice has been widely studied across the world. Interestingly Sinha et al. (2002) identified that it would be interesting to study the influence of purchase characteristics of shoppers on store choice. Even after 10 years, research publications related to this area are very little. Recently Ali et al. (2010) indicated that emerging markets especially where organized retail is still in its early stages are less researched. Hence in this research paper we have studied the influence of purchase characteristics on store choice in Kadapa where organized retail is still in its early stages.
\end{abstract}

Keywords: purchase characteristics, store choice, emerging markets, India

\section{Introduction}

The Indian retail industry has scaled impeccable growth over the last decade with an amiable acceptance to organized retailing formats. The Rs.18 673 billion (US\$ 401 billion) Indian retail market entails only 6 per cent of itself as organized retail segment as of 2010, according to Booz and Co. (India) Pvt. Ltd. Hence there is a great potential to be explored by domestic and international players. The industry is maturing towards modern concept of retailing, cornering the conventional unorganized family-owned businesses. Traditional markets are making way for new formats such as departmental stores, hypermarkets, supermarkets and specialty stores.

Food and groceries is considered to be the largest segment in organized retail accounting for about 58 per cent of the total retail sales during 2010. According to Mr. Raghav Gupta, Principal, Booz and Co., over the next five years, organized food retail (through convenience stores, super markets and hyper markets) is expected to grow by over four times from the current US\$ 8 billion.

Growth in Indian organized retail is driven by changing consumption patterns, favorable demographics, expanding middle class, etc. Hence consumers will continue to drive the growth by expanding the market and compelling retailers to widen their offerings in terms of brands and in terms of variety.

We have entered the 21 st century at a time when the demography of our small town and rural population is changing significantly to drive organized retail growth. With the influence of visual media, urban consumer trends have spread across the rural and small town areas also. Favorable income demographics, increasing population of young people joining the workforce with considerably higher disposable income, has unleashed new possibilities for retail growth even in small towns and rural areas. Thus, 85 per cent of the retail boom which was focused only in the metros has started to infiltrate towards smaller cities and towns. These smaller cities and towns where organized retail is still in its early stages are classified as emerging Indian markets (Ali, Kapoor \& Moorthy, 2010).

However, what is important to understand is that the Indian consumer, no matter where he or she is or what category he or she belongs to, still looks for a good bargain. This is a unique Indian characteristic. Successful retailers are those who are able to adapt and change to the environment and develop new ways of attracting 
customers.

\subsection{About Kadapa}

Kadapa is located in Andhra Pradesh state of India. As per provisional reports of Census India, population of Kadapa in 2011 is 341 823; of which male and female are 171797 and 170026 respectively. In education section, total literates in Kadapa are 242540 of which 131847 are males while 110693 are females. Average literacy rate of Kadapa is 79.38 per cent of which male and female literacy was 86.22 and 72.54 per cent. Children in the age group of 0-6 years form 10.62 per cent of total population of Kadapa.

Whatever development we see in Kadapa today has happened only in the past 5 years. In the past five years there has been tremendous growth related to organized retail, especially in food and clothing sectors. These developments have brought about a change in the shopping behavior of the population. Being an emerging economy, Kadapa still has tremendous opportunities in organized retail businesses.

\section{Review of Literature}

Store choice is primarily a cognitive process (Sinha, Banerjee \& Uniyal, 2002). More than the reality the consumer depends on his perception when choosing a store to shop (Morschett, Swoboda \& Schramm-Klein, 2005).

Attitude towards a retail store is influenced by shopping motives much more than the perception of store attributes (Morschett et al., 2005). Attitude towards a particular store influences store choice decision and also attitudes differ based on socioeconomic profile (Hallsworth, 1991). Choice of a particular store depends upon the personality, social class and economic background of the shoppers (Dodge \& summer, 1969; Aaker \& jones, 1971).

Store choice is significantly dependent on age and gender (Sinha et al., 2002). In an emerging economy, women are of the view that large stores provide more benefits compared to small retail stores (Paswan, Pineda \& Ramirez, 2010).

Based on Proximity, financial considerations, quality of food products and store characteristics a food store is chosen (Krukowski, McSweeney, Sparks \& West, 2012). Location is one of the most important factors considered in store choice decision (Meyer \& Eagle, 1982). Even though location is one of the most important factors considered in store choice, overall purpose and distance from home/workplace are also considered while choosing a store to shop (Brooks, Kaufmann \& Lichtenstein, 2004).

Convenience and merchandise quality are the primary reasons behind store choice (Sinha et al., 2002). In an emerging economy preference of market place for food and grocery purchase is based mostly on convenience (Ali et al., 2010).

Overall store assortment is evaluated by consumers before choosing a store to shop for favourite brands (Amine $\&$ cadenat, 2003). In more than $80 \%$ of the cases store choice depends on wide selection and low cost (Adam \& Louviere, 1996).

In the evolving Indian market shoppers seek more entertainment value compared to the functional value of shopping and based on the shopper's orientation store choice also varies (Sinha, 2003). Elderly shoppers choose a particular store based on its entertainment value and not on its proximity to the residence (Lumpkin, Greenberg \& Goldstucker, 1985).

Various alternatives are evaluated using available information simultaneously by the shopper before choosing to shop in a particular store (Fotheringham, 1988). Pre-purchase information influences store choice. Speciality stores are chosen by shoppers who have more pre purchase information (Dash, Schiffman \& Berenson, 1976). For do-it-yourself (DIY) products store choice is dependent on the task that has to be performed by shoppers after purchase. (Kenhove, Wulf \& Waterschoot, 1999). Store-level promotions influence store choice, but adapting store-level promotions to shopper characteristics is not relevant (Volle, 2001).

\section{Need for the Study}

With the advent of organized retail the phenomenon of store choice started to gain much more importance in India. As the retail market for food and grocery constitutes a major portion of retailing in India, there is growing need to identify the reasons/motives behind grocery store choice.

Literature indicates that store choice has been widely studied across the world. Interestingly Sinha et al., (2002) identified that it would be interesting to study the influence of purchase characteristics of shoppers on store choice as reflected in pre-purchase information gathering, involvement with the store, frequency and value of 
purchase, and understanding the inter-relationship of these variables. Even after 10 years, research publications related to this area are very little.

Recently Ali et al., (2010) indicated that emerging markets especially where organized retail is still in its early stages are less researched.

Hence in this research paper we have studied the influence of purchase characteristics on store choice in Kadapa where organized retail is still in its early stages.

\section{Research Methodology}

\subsection{Research Question}

1) Why do consumers shop at "MORE" supermarket outlets in Kadapa?

\subsection{Research Objectives}

This study has been conducted with the following objectives in view:

1) To identify the main reason behind choosing to shop in "MORE" outlet.

2) To study the influence of purchase characteristics of the shopper on store choice.

3) To understand the inter-relationship between purchase characteristics.

4) To analyze the relationship between demographic characteristics and purchase characteristics of the shopper

\subsection{Hypotheses}

Following null hypotheses were formulated based on the above objectives:

1) Purchase characteristics of the shopper does not influence store choice decision.

2) Purchase characteristics are not inter-related.

3) Demographic characteristics do not influence purchase characteristics

\subsection{Research Design}

Descriptive cross-sectional research design was followed to conduct the study as it is simple and flexible in nature. Also it is the most commonly used design in marketing research.

\subsection{Data Collection Instrument}

Customers were surveyed using a structured questionnaire containing two parts. In the first part questions relating to shopping motives and purchase characteristics were included. In the second part questions relating to socio-demographic information like age, gender, family size, household income, occupation and locality of residence was included.

\subsection{Pilot Testing the Data Collection Instrument}

The questionnaire was first pilot tested with 10 customers in 2 "MORE" super market outlets in Kadapa to identify flaws in the questionnaire design and content. After the pilot test the questionnaire which mostly contained open ended questionnaires was modified into a questionnaire containing closed ended questionnaire, as customers could not think about possible choices without the aid of multiple choices.

\subsection{Data Collection and Sample}

The empirical data was collected from two "MORE" super market outlet operating in Kadapa on the first Sunday (weekend) and the following Wednesday (weekday) of a month. After getting permission from the store manager, the data was collected through mall intercept survey method. Customers were selected based on convenience. About 181 valid questionnaires were collected.

\subsection{Data Analysis}

Frequency tables were formed, cross tabulations were done and a simple statistical analysis was carried out. Chi square test was performed to analyse the relationship between variables. Strength of association between variables was established using measures of contingency coefficient $\mathrm{C}$ and Cramer's V. 


\section{Analysis and Findings}

Table 1. Reason for preferring "MORE"

\begin{tabular}{lll}
\hline Reason for preferring "MORE" & No of respondents & Percentage \\
\hline Quality Products & 59 & 32.6 \\
Accept SODEXO coupons & 28 & 15.5 \\
Offers & 34 & 18.8 \\
Self service & 25 & 13.8 \\
Near residence & 30 & 16.6 \\
Others-Status & 5 & 2.8 \\
Total & 181 & 100 \\
\hline
\end{tabular}

From Table 1 we found that about 33 per cent of customers shop in "MORE" because they wanted to buy quality products. About 30 per cent shop as it is convenient (self-service and near residence). Around 3 per cent of customers shop because they consider shopping in "MORE" as a status symbol. Around 34 per cent shop for value (SODEXO and offers). Previous reports (Cronin et al., 2000; Dodds et al., 1991) suggest that customers who shop for quality, convenience and status are not price sensitive whereas customers who shop for value are price sensitive. Hence 66 per cent of customers who shop at "MORE" are not price sensitive and 34 per cent are sensitive to price.

Table 2. Influence of purchase characteristics of the shopper on store choice and their measures of strength of association

\begin{tabular}{lllllll}
\hline Relationships & $\begin{array}{l}\text { Pearson } \\
\text { Chi-square }\end{array}$ & $\begin{array}{l}\text { Degree } \\
\text { freedom }\end{array}$ & $\begin{array}{l}\text { of } \\
\text { value }\end{array}$ & $\begin{array}{l}\text { Significance } \\
90 \text { per cent }\end{array}$ & $\begin{array}{l}\text { Contingency } \\
\text { coefficient C }\end{array}$ & Cramer's V \\
\hline $\begin{array}{l}\text { Pre-purchase } \\
\text { info. }\end{array}$ & 14.039 & 10 & 0.171 & Independent & -- & 0.197 \\
$\begin{array}{l}\text { Possession of } \\
\text { loyalty card }\end{array}$ & 10.495 & 5 & 0.062 & Dependent & -- & 0.241 \\
$\begin{array}{l}\text { Frequency of } \\
\text { visits }\end{array}$ & 54.853 & 25 & 0.001 & Dependent & 0.482 & 0.246 \\
$\begin{array}{l}\text { Amt spent per } \\
\text { month }\end{array}$ & 75.423 & 25 & 0.000 & Dependent & 0.590 & 0.327 \\
$\begin{array}{l}\text { Amt spent per } \\
\text { visit }\end{array}$ & 96.552 & 25 & 0.000 & Dependent & 0.542 & 0.289 \\
$\begin{array}{l}\text { Mode } \\
\text { payment of }\end{array}$ & 170.271 & 15 & 0.000 & Dependent & -- & 0.560 \\
\hline
\end{tabular}

Based on chi square analysis it is found that except pre-purchase information all other purchase characteristics studied influence store choice at 90 per cent confidence level. But pre-purchase information influences store choice at 80 per cent confidence level. Hence it is concluded that purchase characteristics of the shopper influences store choice decision. There by first null hypothesis is rejected (Refer Table 2).

From the obtained contingency coefficient it can be inferred that the association between amount spent per month, amount spent per visit and frequency of visits in relation to store choice is high (Refer Table 2).

Based on Cramer's V it is found that the association between pre-purchase info, possession of loyalty card, frequency of visits and amount spent per visit in relation to store choice is low. Again based on Cramer's V the association between amount spent per month in relation to store choice is moderate and association between mode of payment in relation to store choice is high (Refer Table 2). 
Table 3. Inter-relationship between purchase characteristics

\begin{tabular}{|c|c|c|c|c|c|}
\hline Relationships & $\begin{array}{l}\text { Pearson } \\
\text { Chi-square } \\
\text { value }\end{array}$ & $\begin{array}{l}\text { Degree } \\
\text { freedom }\end{array}$ & of & $\begin{array}{l}\text { Critical } \\
\text { value }\end{array}$ & $\begin{array}{l}\text { Significance at } 90 \text { per } \\
\text { cent confidence }\end{array}$ \\
\hline $\begin{array}{l}\text { Amount spent } \quad \text { per } \\
\text { month-Pre-purchase info. }\end{array}$ & 7.253 & 10 & & 0.701 & Independent \\
\hline $\begin{array}{l}\text { Amount spent } \\
\text { month-Frequency of visits }\end{array}$ & 23.095 & 25 & & 0.572 & Independent \\
\hline $\begin{array}{l}\text { Possession of loyalty } \\
\text { card-Amount spent per visit }\end{array}$ & 3.275 & 5 & & 0.658 & Independent \\
\hline $\begin{array}{l}\text { Possession of loyalty card -Mode } \\
\text { of payment }\end{array}$ & 0.653 & 3 & & 0.884 & Independent \\
\hline
\end{tabular}

When inter-relationship between purchase characteristics were studied using chi-square test it was found that pre-purchase information and frequency of visits in relation to amount spent per month are independent of each other. Again amount spent per visit and modes of payment in relation to possession of loyalty card are independent (Refer Table 3). Hence second null hypothesis is partially accepted.

Table 4. Inter-relationship of purchase characteristics and their measures of strength of association

\begin{tabular}{|c|c|c|c|c|c|c|}
\hline Relationships & $\begin{array}{l}\text { Pearson } \\
\text { Chi-square } \\
\text { value }\end{array}$ & $\begin{array}{l}\text { Degree of } \\
\text { freedom }\end{array}$ & $\begin{array}{l}\text { Critical } \\
\text { value }\end{array}$ & $\begin{array}{l}\text { Significance at } \\
90 \text { per cent }\end{array}$ & $\begin{array}{l}\text { Contingency } \\
\text { coefficient C }\end{array}$ & Cramer's V \\
\hline $\begin{array}{l}\text { Amount spent per } \\
\text { month-Possession } \\
\text { of loyalty card }\end{array}$ & 30.821 & 5 & 0.000 & Dependent & -- & 0.413 \\
\hline $\begin{array}{l}\text { Amount spent per } \\
\text { month -Mode of } \\
\text { payment }\end{array}$ & 35.802 & 15 & 0.002 & Dependent & -- & 0.257 \\
\hline $\begin{array}{l}\text { Amount spent per } \\
\text { month -Amount } \\
\text { spent per visit }\end{array}$ & 186.686 & 25 & 0.000 & Dependent & 0.713 & 0.454 \\
\hline $\begin{array}{l}\text { Amount spent per } \\
\text { visit-Frequency } \\
\text { of visits }\end{array}$ & 54.508 & 25 & 0.000 & Dependent & 0.481 & 0.245 \\
\hline $\begin{array}{l}\text { Amount spent per } \\
\text { visit-Mode of } \\
\text { payment }\end{array}$ & 33.217 & 15 & 0.004 & Dependent & -- & 0.247 \\
\hline $\begin{array}{ll}\text { Frequency } & \text { of } \\
\text { visits -Mode } & \text { of } \\
\text { payment } & \end{array}$ & 24.218 & 15 & 0.061 & Dependent & -- & 0.211 \\
\hline $\begin{array}{l}\text { Frequency of } \\
\text { visits-Possession } \\
\text { of loyalty card }\end{array}$ & 9.828 & 5 & 0.080 & Dependent & -- & 0.233 \\
\hline $\begin{array}{l}\text { Possession of } \\
\text { loyalty } \\
\text { card-Pre-purchase } \\
\text { info. }\end{array}$ & 5.466 & 2 & 0.065 & Dependent & -- & 0.174 \\
\hline
\end{tabular}

By applying chi-square test it was found that amount spent per month is associated with possession of loyalty 
card, mode of payment and amount spent per visit. Amount spent per visit is also related to frequency of visits and mode of payment. Frequency of visits is associated with mode of payment and possession of loyalty card. Finally association between possession of loyalty card and pre purchase information was also confirmed. All the above associations were significant at 90 per cent confidence level (Refer Table 4).

Strength of association between inter-relationships of purchase characteristics were established using measures of contingency coefficient $\mathrm{C}$ and Cramer's V.

Contingency coefficient $\mathrm{C}$ confirms that amount spent per visit is strongly associated with amount spent per month and frequency of visits (Refer Table 4).

Based on Cramer's V it can be inferred that amount spent per month's influence on possession of loyalty card and amount spent per visit is high (Refer Table 4).

Also Cramer's V confirms that amount spent per visit's influence on frequency of visits and mode of payment is low. Mode of payment's influence on amount spent per month is low. Frequency of visits' influence on possession of loyalty card and mode of payment is also low (Refer Table 4).

Table 5. Inter-relationship of purchase characteristics and their measures of strength of association

\begin{tabular}{lllllll}
\hline Relationships & & $\begin{array}{l}\text { Pearson } \\
\text { Chi-square }\end{array}$ & $\begin{array}{l}\text { Degree } \\
\text { freedom }\end{array}$ & $\begin{array}{l}\text { of } \\
\text { valitical }\end{array}$ & $\begin{array}{l}\text { Significance at } \\
85 \text { per cent }\end{array}$ & $\begin{array}{l}\text { Cramer's } \\
\text { V }\end{array}$ \\
\hline $\begin{array}{l}\text { Frequency of visits-Pre-purchase } \\
\text { info. }\end{array}$ & 14.739 & 10 & 0.142 & Dependent & 0.202 \\
$\begin{array}{l}\text { Mode of payment-Pre-purchase } \\
\text { info. }\end{array}$ & 9.388 & 6 & 0.153 & Dependent & 0.161 \\
$\begin{array}{l}\text { Amount } \\
\text { visit-Pre-purchase info. }\end{array}$ & spent & 15.584 & 10 & 0.112 & Dependent & 0.207 \\
\hline
\end{tabular}

At 85 per cent confidence level it was established that pre-purchase information is significantly associated with frequency of visits, mode of payment and amount spent per visit (Refer Table 5).

Again Cramer's V proves that pre-purchase information's influence on possession of loyalty card, frequency of visits, mode of payment and amount spent per visit is low (Refer Table 5).

Table 6. Influence of gender of the shopper on purchase characteristics

\begin{tabular}{lllllll}
\hline Relationships & $\begin{array}{l}\text { Pearson } \\
\text { Chi-square }\end{array}$ & $\begin{array}{l}\text { Degree } \\
\text { freedom }\end{array}$ & $\begin{array}{c}\text { of } \\
\text { Critical } \\
\text { value }\end{array}$ & $\begin{array}{l}\text { Significance } \\
90 \text { per cent }\end{array}$ & $\begin{array}{l}\text { Contingency } \\
\text { coefficient C }\end{array}$ & Cramer's V \\
\hline $\begin{array}{l}\text { Pre-purchase } \\
\text { info. }\end{array}$ & 7.563 & 2 & 0.023 & Dependent & - & 0.204 \\
$\begin{array}{l}\text { Possession of } \\
\text { loyalty card }\end{array}$ & 0.868 & 1 & 0.351 & Independent & 0.069 & 0.069 \\
$\begin{array}{l}\text { Frequency of } \\
\text { visits }\end{array}$ & 14.015 & 5 & 0.016 & Dependent & - & 0.278 \\
$\begin{array}{l}\text { Amt spent per } \\
\text { month }\end{array}$ & 4.969 & 5 & 0.420 & Independent & - & 0.166 \\
$\begin{array}{l}\text { Amt spent per } \\
\text { visit }\end{array}$ & 14.073 & 5 & 0.015 & Dependent & - & 0.279 \\
$\begin{array}{l}\text { Mode } \\
\text { payment }\end{array}$ & 8.806 & 3 & 0.032 & Dependent & - & 0.221 \\
\hline
\end{tabular}

By applying chi-square it was found that except for possession of loyalty card and amount spent per month, all other purchase characteristics are influenced by the gender of the shopper (Refer Table 6).

Strength of association tests also proves this point and clarifies that the strength of association between gender and purchase characteristics is not very high (Refer Table 6). 
Table 7. Influence of age of the shopper on purchase characteristics

\begin{tabular}{|c|c|c|c|c|c|c|}
\hline Relationships & $\begin{array}{l}\text { Pearson } \\
\text { Chi-square }\end{array}$ & $\begin{array}{l}\text { Degree of } \\
\text { freedom }\end{array}$ & $\begin{array}{l}\text { Critical } \\
\text { value }\end{array}$ & $\begin{array}{l}\text { Significance at } \\
90 \text { per cent }\end{array}$ & $\begin{array}{l}\text { Contingency } \\
\text { coefficient C }\end{array}$ & Cramer's V \\
\hline $\begin{array}{l}\text { Pre-purchase } \\
\text { info. }\end{array}$ & 9.764 & 8 & 0.282 & Independent & - & 0.164 \\
\hline $\begin{array}{l}\text { Possession of } \\
\text { loyalty card }\end{array}$ & 18.446 & 4 & 0.001 & Dependent & - & 0.319 \\
\hline $\begin{array}{l}\text { Frequency of } \\
\text { visits }\end{array}$ & 27.584 & 20 & 0.120 & Independent & - & 0.195 \\
\hline $\begin{array}{l}\text { Amt spent per } \\
\text { month }\end{array}$ & 46.715 & 20 & 0.001 & Dependent & - & 0.254 \\
\hline $\begin{array}{l}\text { Amt spent per } \\
\text { visit }\end{array}$ & 63.310 & 20 & 0.000 & Dependent & - & 0.296 \\
\hline $\begin{array}{l}\text { Mode of } \\
\text { payment }\end{array}$ & 38.737 & 12 & 0.000 & Dependent & - & 0.267 \\
\hline
\end{tabular}

Chi-square test points out that except for pre-purchase information collection methods and frequency of visits, all other purchase characteristics are influenced by the age of the shopper (Refer Table 7).

Cramer's V points out that, there is moderate association between age and possession of loyalty card, whereas the association between age and other purchase characteristics is low (Refer Table 7).

Table 8. Influence of family size of the shopper on purchase characteristics

\begin{tabular}{|c|c|c|c|c|c|c|}
\hline Relationships & $\begin{array}{l}\text { Pearson } \\
\text { Chi-square }\end{array}$ & $\begin{array}{l}\text { Degree of } \\
\text { freedom }\end{array}$ & $\begin{array}{l}\text { Critical } \\
\text { value }\end{array}$ & $\begin{array}{l}\text { Significance at } \\
90 \text { per cent }\end{array}$ & $\begin{array}{l}\text { Contingency } \\
\text { coefficient C }\end{array}$ & Cramer's V \\
\hline $\begin{array}{l}\text { Pre-purchase } \\
\text { info. }\end{array}$ & 3.294 & 4 & 0.510 & Independent & 0.134 & 0.095 \\
\hline $\begin{array}{l}\text { Possession of } \\
\text { loyalty card }\end{array}$ & 0.852 & 2 & 0.653 & Independent & - & 0.069 \\
\hline $\begin{array}{l}\text { Frequency of } \\
\text { visits }\end{array}$ & 9.606 & 10 & 0.476 & Independent & - & 0.163 \\
\hline $\begin{array}{l}\text { Amt spent per } \\
\text { month }\end{array}$ & 17.842 & 10 & 0.058 & Dependent & - & 0.222 \\
\hline $\begin{array}{l}\text { Amt spent per } \\
\text { visit }\end{array}$ & 9.603 & 10 & 0.476 & Independent & - & 0.163 \\
\hline $\begin{array}{l}\text { Mode } \\
\text { payment }\end{array}$ & 11.096 & 6 & 0.085 & Dependent & - & 0.175 \\
\hline
\end{tabular}

Based on Chi-square analysis it is inferred that family size of the shopper does not influence most of the purchase characteristics, except amount spent per month and mode of payment (Refer Table 8).

Strength of association tests points out that even the association that exists is low between family size and purchase characteristics (Refer Table 8).

Table 9. Influence of monthly income of the shopper on purchase characteristics

\begin{tabular}{llllllll}
\hline Relationships & $\begin{array}{l}\text { Pearson } \\
\text { Chi-square }\end{array}$ & $\begin{array}{l}\text { Degree } \\
\text { freedom }\end{array}$ & $\begin{array}{l}\text { of } \\
\text { value }\end{array}$ & $\begin{array}{l}\text { Significance } \\
\text { 90 per cent }\end{array}$ & $\begin{array}{l}\text { Contingency } \\
\text { coefficient C }\end{array}$ & Cramer's V \\
\hline $\begin{array}{l}\text { Pre-purchase } \\
\text { info. }\end{array}$ & 22.816 & 10 & 0.011 & Dependent & - & 0.251 \\
$\begin{array}{l}\text { Possession of } \\
\text { loyalty card }\end{array}$ & 5.744 & 5 & 0.332 & Independent & - & 0.178 \\
$\begin{array}{l}\text { Frequency of } \\
\text { visits }\end{array}$ & 33.662 & 25 & 0.115 & Independent & 0.396 & 0.193 \\
$\begin{array}{l}\text { Amt spent per } \\
\text { month }\end{array}$ & 47.159 & 25 & 0.005 & Dependent & 0.455 & 0.228 \\
$\begin{array}{l}\text { Amt spent per } \\
\text { visit }\end{array}$ & 47.539 & 25 & 0.004 & Dependent & 0.456 & 0.229 \\
$\begin{array}{l}\text { Mode of } \\
\text { payment }\end{array}$ & 16.995 & 15 & 0.319 & Independent & - & 0.177 \\
\hline
\end{tabular}


Chi-square analysis establishes association between monthly household income and amount spent per month / visit and pre-purchase information channel (Refer Table 9).

Strength of association tests show moderate to low association between monthly house hold income and purchase characteristics (Refer Table 9).

Table 10. Influence of occupation of the shopper on purchase characteristics

\begin{tabular}{lllllll}
\hline Relationships & $\begin{array}{l}\text { Pearson } \\
\text { Chi-square }\end{array}$ & $\begin{array}{l}\text { Degree } \\
\text { freedom }\end{array}$ & $\begin{array}{l}\text { of } \\
\text { Vritical } \\
\text { value }\end{array}$ & $\begin{array}{l}\text { Significance } \\
90 \text { per cent }\end{array}$ & $\begin{array}{l}\text { Contingency } \\
\text { coefficient C }\end{array}$ & Cramer's V \\
\hline $\begin{array}{l}\text { Pre-purchase } \\
\text { info. }\end{array}$ & 48.016 & 14 & 0.000 & Dependent & - & 0.364 \\
$\begin{array}{l}\text { Possession of } \\
\text { loyalty card }\end{array}$ & 22.766 & 7 & 0.002 & Dependent & - & 0.355 \\
$\begin{array}{l}\text { Frequency of } \\
\text { visits }\end{array}$ & 44.367 & 35 & 0.133 & Independent & - & 0.221 \\
$\begin{array}{l}\text { Amt spent per } \\
\text { month }\end{array}$ & 71.830 & 35 & 0.000 & Dependent & - & 0.282 \\
$\begin{array}{l}\text { Amt spent per } \\
\text { visit }\end{array}$ & 80.690 & 35 & 0.000 & Dependent & - & 0.299 \\
$\begin{array}{l}\text { Mode } \\
\text { payment of }\end{array}$ & 40.100 & 21 & 0.007 & Dependent & - & 0.272 \\
\hline
\end{tabular}

Based on Chi-square test, it is inferred that the purchase characteristics of the shopper is influenced by the occupation of the shopper, except for frequency of visits (Refer Table 10).

Cramer's V indicates that there exists moderate association between occupation and the purchase characteristics of the shopper (Refer Table 10).

Based on the above inferences from Refer Table 6 to Refer Table 10, we can conclude that most of the purchase characteristics of the shopper are influenced by the demographic characteristics of the shopper. Except for certain associations most of the associations are low. Hence third null hypothesis is partially accepted.

\section{Limitations of the Study}

Survey was conducted at two "MORE" supermarket outlets only, as there are no other supermarkets in Kadapa which are similar in magnitude to "MORE" supermarkets. Hence a comparative study is not practically possible, in the current situation.

\section{Managerial Implications}

In Indian emerging markets where organized retail is still in its early stages understanding the real motive behind store choice is essential for a retailer to get a strong hold on the market. Consumers of emerging markets possess unique characteristics in relation to developed markets. Hence it is important for retailers to study and understand these characteristics for long term success. The findings of this paper will aid these organized retailers in understanding the motive behind store choice for grocery purchase and the influence of purchase characteristics on store choice decision.

Also these findings will help traditional unorganized retailers to identify the reason behind their customer's attraction towards modern retail outlets. By identifying the motives the traditional retailers can formulate strategies to compete with the modern retail outlets and upgrade their retail business as per the expectations of the customers. After all they have been the back bone of Indian food retail for decades together and they have to been given an opportunity to compete.

\section{Future Research}

Research related to store choice, purchase characteristics and their influences in an emerging Indian market is an area which has not been focused appropriately till date. In this research article only a drop of the ocean has been focused upon. When data related to other emerging Indian markets are also collected through research, it would be possible to compare and consolidate the characteristics of these markets to form a complete picture. Hence 
there is lot of scope in this area. Understanding the importance, it is time to initiate more and more research related to shopper characteristics, purchase characteristics, etc. and their influence on shopping behavior in emerging Indian markets.

\section{Conclusion}

For the modern Indian consumer living in big cities, aspiration is the key. It is all about brands, lifestyles and show-off value, which are followed by quality and finally price. Whereas traditional rural and small town consumer, is driven primarily by price followed by aspiration and then quality.

The rise of organized retailing has transformed the way Indian consumer spends and has brought a great change in the quality of life of the people in the metro and non-metro cities of India. Retailers are using all the available media like print, visual etc. to their utmost extent and are able to penetrate in a variety of consumer goods, electronic items, and FMCG products deep inside the semi-urban and other interior parts of India. It is found that the gap between the living standards of the consumers of metros and the non-metro cities is narrowing down day by day. Hence findings of this study will help grocery retailers to understand customers of these emerging markets in a better way.

\section{References}

Aaker, D. A., \& Jones, M. J. (1971). Modelling Store Choice Behaviour. Journal of Marketing Research, 8, 38-42. http://dx.doi.org/10.2307/3149723

Ali, J., Kapoor, S., \& Moorthy, J. (2010). Buying behaviour of consumers for food products in an emerging economy. British Food Journal, 112(2), 109-124. http://dx.doi.org/10.1108/00070701011018806

Amine, A., \& Cedenat, S. (2003). Efficient retailer assortment: A consumer choice evaluation perspective. International Journal of Retail and Distribution Management, 31(10), 486-497. http://dx.doi.org/10.1108/09590550310497012

Brooks, C., Kaufmann, P. J., \& Lichtenstein, D. R. (2004). Travel configuration on consumer trip-chained store choice. Journal of Consumer Research, 31(2), 241-248. http://dx.doi.org/10.1086/422104

Cronin, J. J., Brady, M. K., \& Hult, G. T. M. (2000). Assessing the effects of quality, value, and customer satisfaction on consumer behavioral intentions in service environments. Journal of Retailing, 76(2), 193-218. http://dx.doi.org/10.1016/S0022-4359(00)00028-2

Dash, J. F., Schiffman, L. G., \& Berenson, C. (1976). Information Search and Store Choice. Journal of Advertising Research, 16(3), 35-40.

Dodds, W. B., Monroe, K. B., \& Grewal, D. (1991). Effects of price, brand, and store information on buyers' product evaluations. Journal of Marketing Research, 28(3), 307-319. http://dx.doi.org/10.2307/3172866

Dodge, R. H., \& Summer, H. H. (1969). Choosing between Retail Stores. Journal of Retailing, 45(3), 11-21.

Finn, A., \& Louviere, J. J. (1996). Shopping center image, consideration and choice anchor store contribution. Journal of Business Research, 35, 241-251. http://dx.doi.org/10.1016/0148-2963(95)00129-8

Fotheringham, A. S. (1988). Consumer store choice and choice set definition. Marketing Science, 7(3), 299-310. http://dx.doi.org/10.1287/mksc.7.3.299

Hallsworth, A. (1991). Who shops where? And why? International Journal of Retail and Distribution Management, 19(3), 19-26. http://dx.doi.org/10.1108/09590559110144223

Kenhove, P. V., Wulf, K. D., \& Waterschoot, W. V. (1999). The impact of task definition on store-attribute $\begin{array}{lllll}\text { saliences and store choice. Journal of retailing, } & 75(1), & 125-137 .\end{array}$ http://dx.doi.org/10.1016/S0022-4359(99)80007-4

Krukowski, R. A., McSweeney, J., Sparks, C., \& West, D. S. (2012). Qualitative study of influences on food store choice. Appetite, 59(2), 510-516. http://dx.doi.org/10.1016/j.appet.2012.06.019

Lumpkin, J. R., Greenberg, B. A., \& Goldstucker, J. L. (1985). Marketplace Needs of the Elderly: Determinant Attributes and Store Choice. Journal of Retailing, 61(2), 75-105.

Meyer, R. J., \& Eagle, T. C. (1982). Context induced parameter instability in a disaggregate-stochastic model of store choice. Journal of Marketing Research, 62-71. http://dx.doi.org/10.2307/3151531

Morschett, D., Swoboda, B., \& Schramm-Klein, H. (2005). Perception of store attributes and overall attitude towards grocery retailers: The role of shopping motives. The International Review of Retail, Distribution and Consumer Research, 15(4), 423-447. http://dx.doi.org/10.1080/09593960500197552 
Paswan, A., Pineda, M. D. S., \& Ramirez, F. C. S. (2010). Small versus large retail stores in an emerging $\begin{array}{lllll}\text { market-Mexico. Journal of } & \text { Business }\end{array}$ http://dx.doi.org/10.1016/j.jbusres.2009.02.020

Sinha, P. K. (2003). Shopping Orientation in the evolving Indian Market. Vikalpa, 28(2), 13-21.

Sinha, P. K., \& Banerjee, A. (2004). Store choice behavior in an evolving market. International Journal of Retail and Distribution Management, 32(10), 482-494. http://dx.doi.org/10.1108/09590550410558626

Sinha, P. K., Banerjee, A., \& Uniyal, D. P. (2002). Deciding Where to Buy: Store Choice Behaviour of Indian Shoppers. Vikalpa, 27(2), 13-28.

Uncles, M., \& Hammond, K. (1995). Grocery store patronage. The International Review of Retail, Distribution and Consumer Research, 5(3), 287-302. http://dx.doi.org/10.1080/09593969500000019

Volle, P. (2001). The short-term effect of store-level promotions on store choice, and the moderating role of individual variables. Journal of Business Research, 53(2), http://dx.doi.org/10.1016/S0148-2963(99)00074-0

\section{Copyrights}

Copyright for this article is retained by the author(s), with first publication rights granted to the journal.

This is an open-access article distributed under the terms and conditions of the Creative Commons Attribution license (http://creativecommons.org/licenses/by/3.0/). 